\title{
Basement Characteristic Western Part of Java, Indonesia; Case Study in Bayah Area, Banten Province
}

\author{
Aton Patonah" ${ }^{\#}$ Haryadi Permana* \\ ${ }^{\#}$ Faculty of Geological Engineering, Padjadjaran University, Sumedang KM 21. Jatinangor, 45363, West Java, Indonesia \\ E-mail: a.patonah@unpad.ac.id \\ ${ }^{*}$ Research Center for Geotechnology LIPI, Jl Sangkuriang Bandung 40135, West Java, Indonesia \\ E-mail: hpharper.permana@gmail.com
}

\begin{abstract}
Recent study reveals that in Bayah Complex, $20 \mathrm{~km}$ west of Ciletuh Melange Complex, discovered a metamorphic rock that interpreted as the basement of Java. This research aims to know the characteristic of metamorphic in Bayah areas. The result shows that the metamorphic rocks of Bayah Geological Complex are dominated by mica schist group, i.e., muscovite schist, muscovite-biotite schist, garnet biotite schist and chlorite schist associated with Pelitic - Psammitic protolith. The amphibolite, epidote amphibolite and actinolite schist found were metamorphosed of mafic rock protolith. All of them have been deformed and altered. Based on mineral assemblage, mica schist group included lower greenschist - epidote-amphibolite facies, whereas actinolite schist, epidote amphibolite schist, and hornblende schist included greenschist facies, epidote-amphibolite facies, and amphibolite facies respectively. Based on the data, these metamorphic rocks are associated with the orogenic style. The metamorphic rocks exposed to the surface through a complex process since Late Cretaceous. Metamorphic rocks have been deformed, folded and faulted since its formation. Its possible this rock was uplifted to the surface due to the intrusion of Cihara Granodiorite.
\end{abstract}

Keywords - Bayah Geological Complex; greenschist facies; amphibolite facies; orogenic style; uplifted.

\section{INTRODUCTION}

The western part of Java is located in the southwest margin of Eurasia or Sunda Block, and it is located in northern part of subduction zone between Eurasian and India - Australia Plate (Figure.1) since Early Crestaceous[1], [2]. As a result of this subduction - accretion, Ciletuh Melange Complex (CMC) were exposed to the surface [1]-[9]. The CMC was formed in the deep-water trench environment of the Cretaceous - Eocene subduction system and known as one of the Java's basement. The basement rocks in CMC are composed by dismembered ophiolite, amphibolite, epidote amphibolite, and greenschist [4], [5], [9]. The age of CMC ranges from Mesozoic to Late Tertiary [6]. This complex is formed by a complicated geological process of subduction, abduction and a combination of collision between plates and back arc thrust complex.

A recent study [10]-[12] reveal that metamorphic rocks are present in Bayah area, Banten Province and on this paper, will be called Bayah Geological Complex (BGC). The BGC situated about $20 \mathrm{~km}$ northwest of CMC. In this area, slate, phyllite, schist, gneiss, quartzite, and amphibolite [10]-[12] that exposed are different from those exposed in CMC [11],
[12]. According to [11], metamorphic rocks that exposed in BGC are Oligocene age. Furthermore, according to a recent study, these metamorphic rocks are the oldest rock (basement) that exposed in this area [11], [12]. The Eocene Bayah Formation stratigraphically overlies these rocks and intruded by Granodiorite Cihara. The geological structure that developed in the area is strike-slip faults with generally horizontal fault and North-Southward direction. This fault is suspected as a trigger for metamorphic rocks exposure in the Bayah region [11]-[13]. One of the faults have North-South direction, and it is separated the Banten and Bogor segments as well as the Southern Mountains. Its position as the tectonic element is considered important because this fault does not only separate the different structural patterns but also controls the pattern of deposition between the segments of Banten and its surroundings [13].

In this paper, we will identify the characteristic of metamorphic rock in Bayah Geological Complex (BGC) based on petrographic analysis to understand the texture, structure, mineral composition and the protolith. The outcome of this research is expected to help reconstruct the geological setting of the western part of Java. 


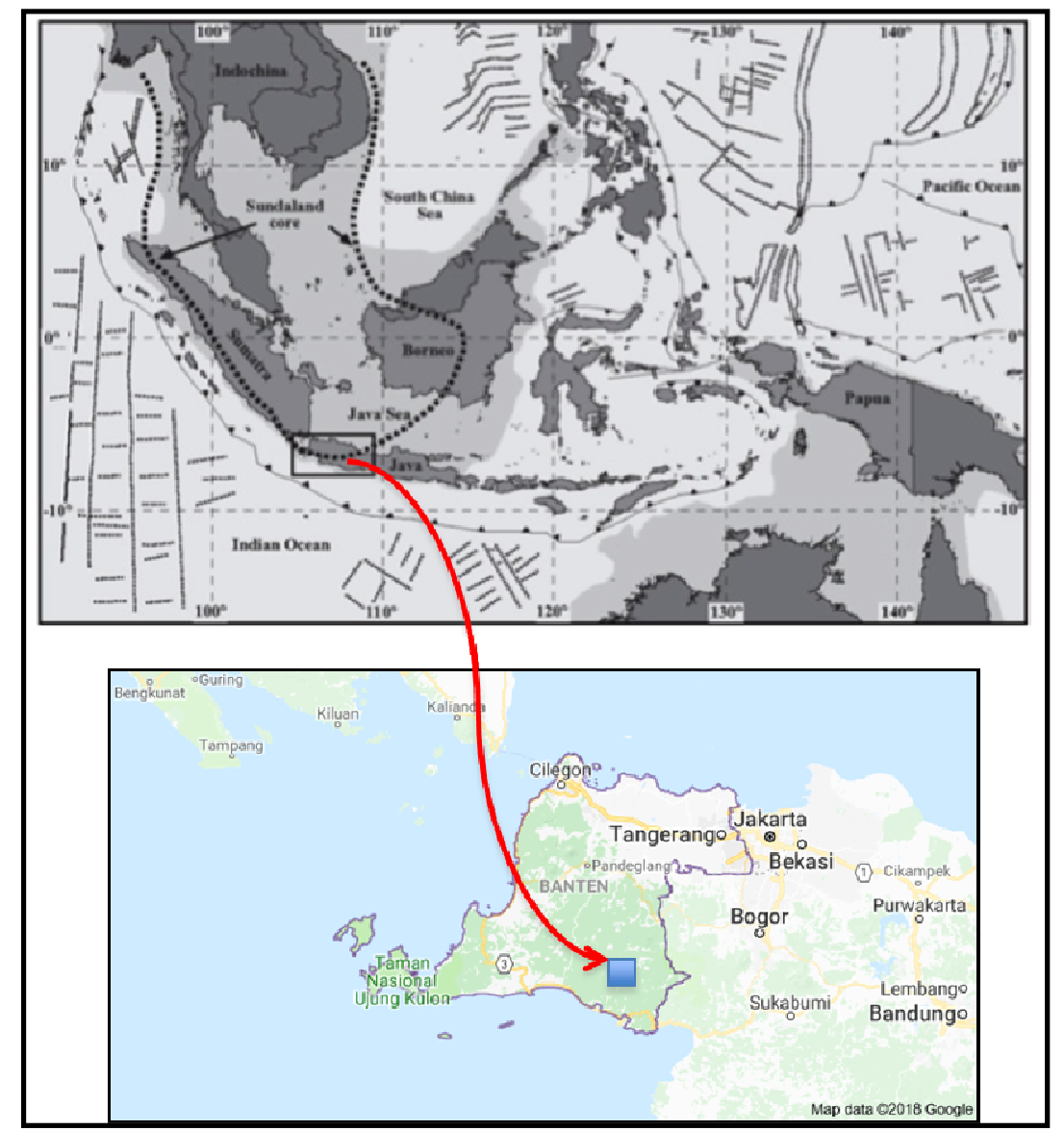

Fig. 1. Location research area (in the box) is part of Sundaland block, subduction zones and political boundaries [2]

\section{MATERIAL AND METHODS}

The object in this study is metamorphic rock. The research methods used are literature study, field observation, and petrography analysis. Literature study included a compilation of the result on geological mapping on Bayah Area from 2014 to 2016, while field observation was conducted between March to April 2017. Petrography analysis of selected samples is completed at Petrology Laboratory, University of Padjadjaran and Research Center for Geotechnology, LIPI Bandung. This analysis is important to determine the texture, structure, composition of mineral, metamorphic rock names and the protolith of the rocks. These methods are necessary, needed to understand the process of metamorphic rock establishment in Bayah Geological Complex exposed.

\section{RESULT AND DISCUSSION}

\section{A. Field Observation}

Field observation in Bayah area has been done at Cisanun River, Cigaber River, Cipager, Cikahuruan, Cibaong River and Cisamiah River (Figure 2). Metamorphic rocks that exposed, in situ and as a block along the river in this area were dominated by mica schist and phyllite, some present slate, greenschist, amphibolite schist, and quartzite. In general, the direction of foliation is dominated by the west to east, some northwest to southeast and north to east. All of the metamorphic rocks have fractured and faulted intensely. The metamorphic rocks mostly oxidated and altered.

1) Mica schist: This rock exposed in Cisanun, Cigaber, Cipager, Cisamiah, Cibaong, and Cikahuruan Rivers. Generally, the rock showed variated foliation with direction trend west to east, some NW to SE and NE to SW (Figure 3a $\& 3 b)$. Also, the rock has folded with asymmetric type, and it has fractured with stress trend NW to SE and NE to SW. Mica schist showed very fine grain - medium grain, variated foliation with direction West to East, some NE to SW, coarse and angular grain, fractured filled by pyrite chlorite and quartz mineral. This rock is dominated by mica and quartz, some present chlorite, feldspare, sericite and garnet. This mica schist is intruded by granodiorite and porphyry andesite.

2) Phyllite: The rock uncovered in Cisanun, Cigaber and Cipager Rivers. The rocks show variation in foliation with relatively west to east trend, some north to south, folded, fractured. This rock shows very fine grain, brown brownish grey color, very hard but brittle and intruded by Porphyry Andesite (Figure 3c).

3) Slate: This rock showed in Cisanun River. It has black color, tough but brittle, have contained very fine grain mineral, much pyrites, with foliation directed NW to SE trend (Figure 3d).

4) Greenschist: This rock exposed in Cisanun River, some found as boulder (floating sample). The rock has fine grain, good foliation, dominated by flat, prismatic and tabular minerals (Figure 3e). 


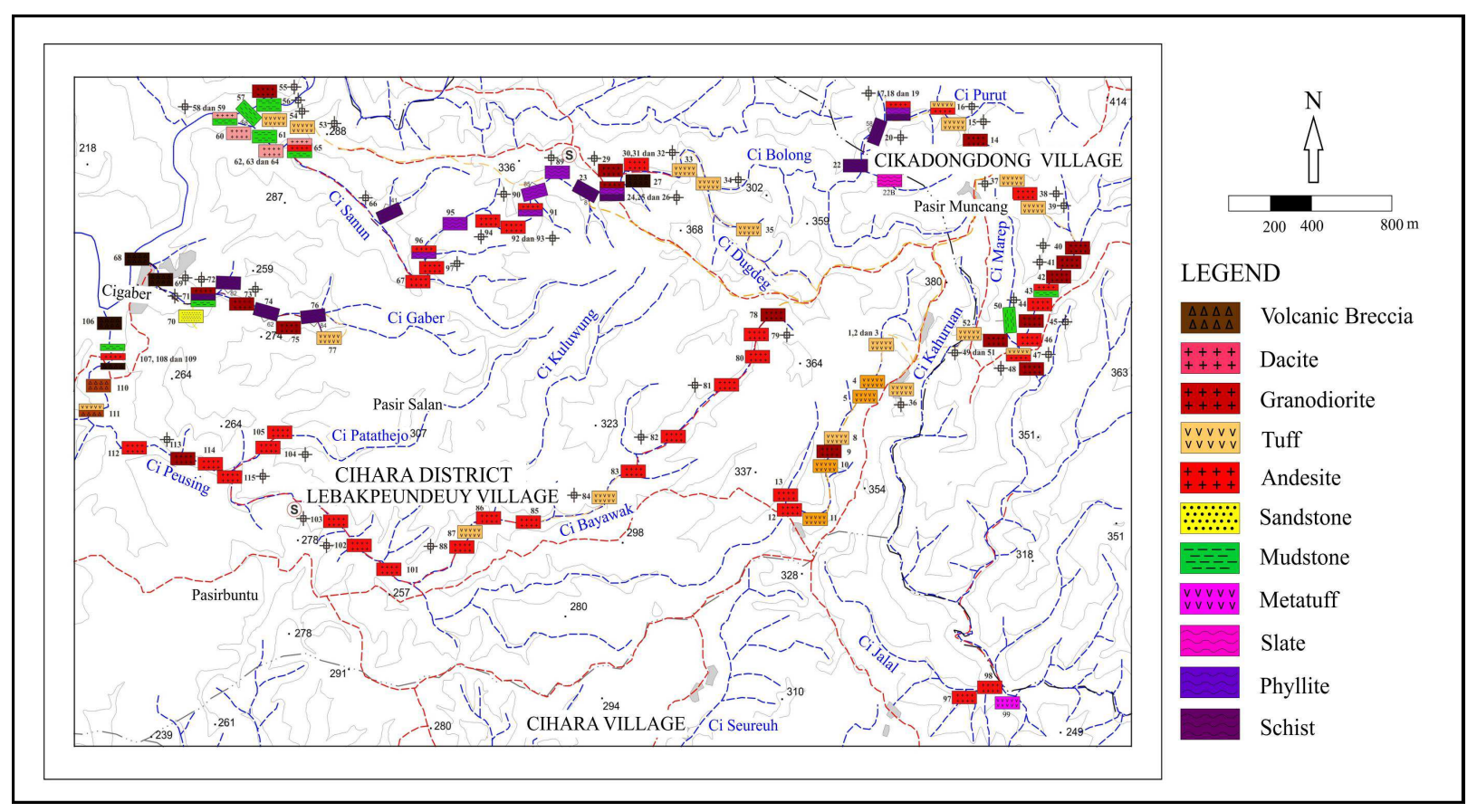

Fig. 2. Field observation of metamorphic rock distribution in Bayah Geological Complex

5) Amphibolite schist: The amphibolite schist exposed at Cisanun, Cigaber and Cipager Rivers. Some of these rocks are present as a boulder (floating sample). The rock has medium grained and angular. Foliation undeveloped well and dominated by amphibole and feldspar mineral, some their fractures were filled by quartz minerals (Figure $3 \mathrm{f}$ ).

\section{B. Petrography}

The petrographic analysis is done on selected metamorphic rocks samples, relatively fresh and slightly altered or weathered. The detail the petrographic analysis is below.

1) Mica schist Group: The mica schist group consist of three types. They are muscovite schist, biotite muscovite schist, and garnet biotite schist. Muscovite schist displayed foliation structure, lepidoblastic - porphyroblastic texture, fine - medium grain, interlaying between phyllosilicate (mica and clay mineral) and tectosilicate (quartz and feldspar), some showed dissected structure and eye's texture, consist of muscovite (40\%), quartz (20\%), some K-feldspar $(10 \%)$, chlorite $(15 \%)$, sphene $(3 \%)$, zircon $(2 \%)$, sericite $(5 \%)$ and opaque mineral $(5 \%)$, some have fractured and filled by chlorite, epidote and quartz mineral (Figure $4 \mathrm{a}$ ). Based on mineral composition, this rock reflected pelitic protolith.

The biotite muscovite schist has good foliation, fine grain - medium grain, lepidoblastic - porphyroblastic texture, some of it showed eye's texture (feldspar present as porphyroblast), consist of biotite $(30 \%)$, muscovite $(15 \%)$, quartz $(25 \%)$, some chlorite (15\%), K-feldspar (10\%) and opaque mineral $(5 \%)$. The rock has fractured filled by chlorite, epidote and quartz mineral. Almost minerals deformed which are characterized by wavy distinction (Figure 4b). Based on mineral composition, the rocks represented semi-pelite - psammitic protolith.
Garnet-biotite schist showed foliation structure, lepidoblastic - porphyroblastic texture, garnet present as porphyroblast texture, very fine - fine grain, consists of quartz $(30 \%)$ and biotite $(35 \%)$ dominantly, some chlorite (20\%), muscovite (5\%), K-feldspar (7\%), garnet (5\%), opaque $(5 \%)$ and oxide mineral $(3 \%)$, have fractured filled by quartz, epidote, chlorite and opaque mineral (Figure 4c). Based on mineral composition, this rock may come from semi-pelite protolith.

2) Amphibolite schist: Amphibolite schist group consist of hornblende schist, epidote amphibolite schist, and actinolite schist. Hornblende schist have green color, showed foliation structure, porphyroblastic and nematoblastic texture, consist of hornblende (50\%) and plagioclase (20\%), some presents actinolite (10\%), chlorite (5\%), quartz (5\%), opaque $(7 \%)$ and oxide minerals $(3 \%)$, have fractured that filled by epidote, chlorite and quartz mineral and almost all minerals have deformed are characterized by wavy extinction (Figure 4d).

Epidote amphibolite schist showed brownish-green color, have medium grained, have foliation structure, porphyroblastic texture, have fractured that filled by chlorite and epidote mineral. This rock consists of hornblende (30\%), plagioclase $(20 \%)$, epidote $(10 \%)$, actinolite $(15 \%)$, chlorite $(15 \%)$, quartz $(5 \%)$ and opaque mineral $(5 \%)$. Based on texture and mineral composition, amphibolite rock and epidote amphibolite can be derived from mafic rock (gabbro).

3) Greenschist: This rock has a green color, have good foliation structure, nematoblastic texture, showed interlaying actinolite and plagioclase, consist of actinolite (45\%), plagioclase $(30 \%)$, some biotite $(5 \%)$, chlorite $(15 \%)$ and quartz $(5 \%)$. Based on the mineral composition, it is called actinolite schist (Figure 4e). 


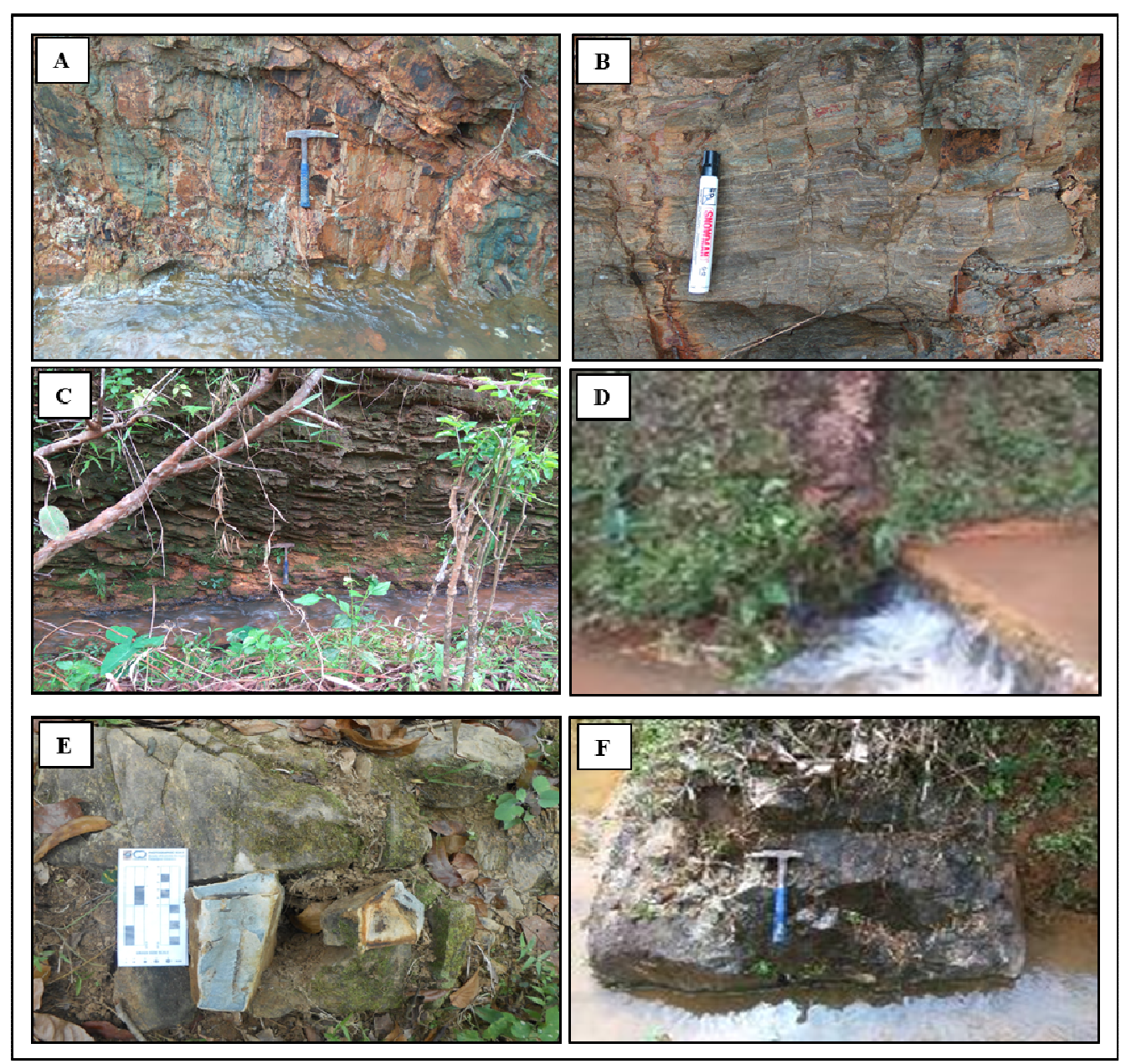

Fig. 3. Almost metamorphic rock that exposed in Bayah Geological Complex has good foliation. (A\&B) Mica schist; (C) Phyllite; (D) Slate; (E) Greenschist; (F) Amphibolite schist.

4) Chlorite Schist: This rock shows brown color, good foliation, porphyroblastic texture, dominated by Chlorite $(40 \%)$, quartz $(25 \%)$ and clay mineral $(25 \%)$, plagioclase $(5 \%)$, opaque mineral $(5 \%)$ (Figure $4 \mathrm{f})$. Based on mineral composition, this rock may come from semi-pelite protolith.

\section{C. $P$ and T Estimation}

Metamorphic mineral assemblage acts as an indicator of the thermal gradient in the crust at the time when the metamorphism took place and can be used to determine the metamorphism of the metamorphic rock. The result of the petrographic analysis shows that metamorphic rocks in the research area are dominated by muscovite-biotite schist, some garnet biotite schist, muscovite schist, hornblende schist, epidote amphibolite, actinolite schist, and chlorite schist.

Furthermore, mineral assemblage can also be used to determine the different metamorphism grade (Table 1A and 1B). At the first stage of metamorphism (prograde metamorphism), shale transformed into slate and phyllite. The composition is dominated by clay mineral, sericite, muscovite, chlorite, quartz, some K-feldspar and plagioclase. It formed at about $200^{\circ} \mathrm{C}$ to $250^{\circ} \mathrm{C}$ and $<230 \mathrm{Mpa}$ [14]. When temperature increase or at high-grade condition than before, K-feldspar and or biotite replaced by Muscovite. Typical assemblages are widespread in psammitic rocks. In the temperature interval between the two limiting equilibria, all four minerals (chlorite + K-feldspar + muscovite + biotite) may occur stably together (Figure 5).

Near $400^{\circ} \mathrm{C}$, the first biotite appears in all poor metapelites [14]. Biotite forms at the expense of K-feldspar and chlorite. The reaction has equilibrium condition at $420^{\circ} \mathrm{C}$ and $350 \mathrm{MPa}$. The first garnet appears in garnet biotite schist at temperatures around $450^{\circ} \mathrm{C}$ and $440 \mathrm{Mpa}$. Fe-rich chlorite begins to be replaced by garnet + biotite between $500^{\circ} \mathrm{C}-520^{\circ} \mathrm{C}$ and $500 \mathrm{Mpa}-1100 \mathrm{Mpa}$ [14]. This rock has retrograde metamorphism which is characterized by biotite margin and some whole this mineral replaced by chlorite dominantly, some muscovite.

Another metamorphic rock in this area with different protolith (mafic rock) is amphibolite schist. These rocks are dominated by hornblende and plagioclase, formed at about $600^{\circ} \mathrm{C}-660^{\circ} \mathrm{C}$ [15] and $400 \mathrm{MPa}-600 \mathrm{MPa}$. In part of hornblende margin replaced by actinolite and chlorite, meanwhile, plagioclase replaced by epidote and chlorite. Actinolite - hornblende association can be found in the low - and medium pressure metamorphic terrains of the greenschist, amphibolite and epidote-amphibolite facies [16]. The data shows that amphibolite schist has retrograde metamorphism to epidote amphibolite schist. The rock may have formed at $<500^{\circ} \mathrm{C}$ and $<300 \mathrm{MPa}$ [17]. 

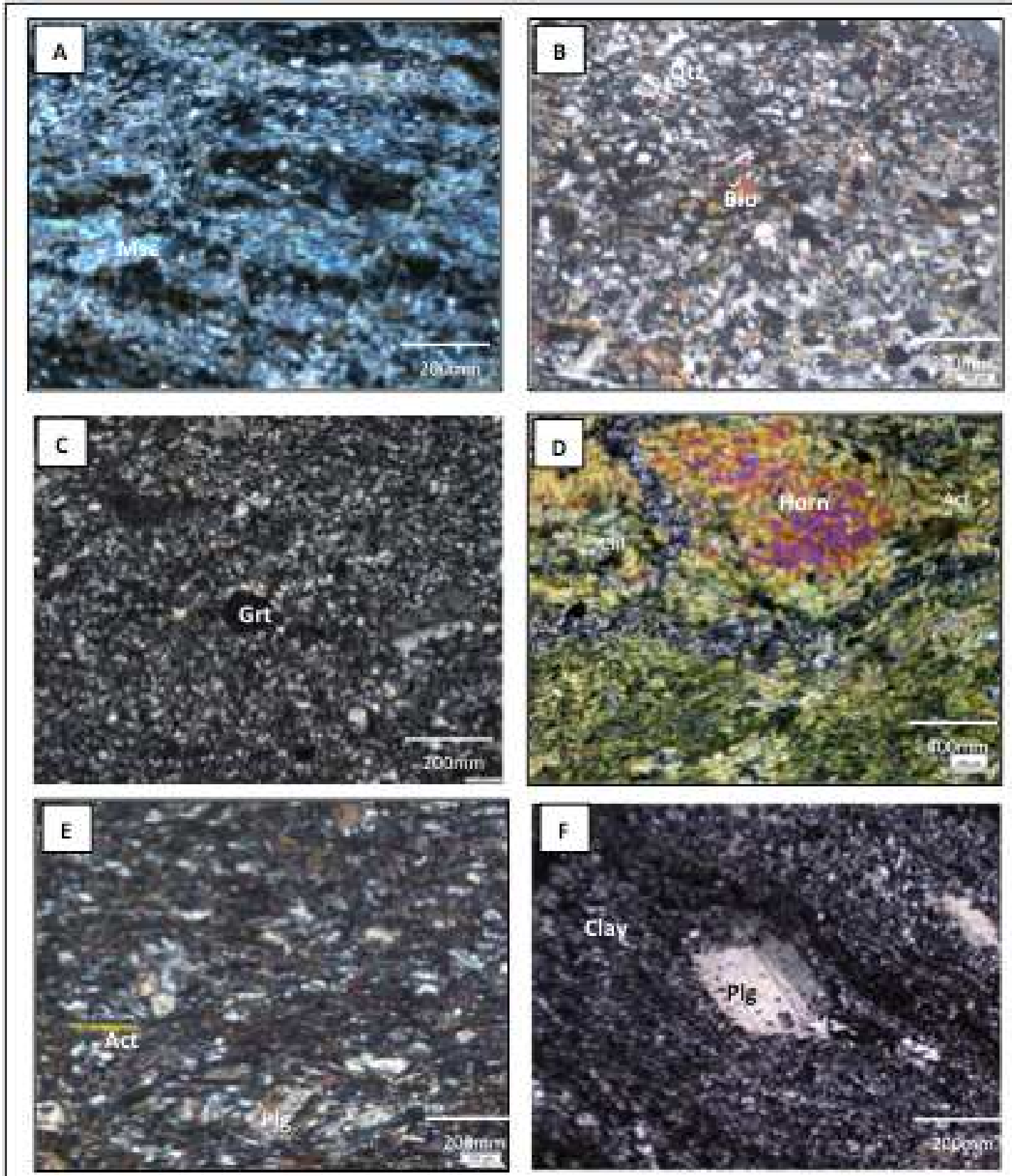

Fig. 4. These represent metamorphic rock in Bayah area showed good foliation. (A) Muscovite schist, (B) Biotite - Muscovite schist, (C ) Garnet Biotite schist, (D) hornblende schist, (E) Actinolite Schist and (F) Quartz Slate.

Actinolite schist consists of actinolite and plagioclase dominantly, some present biotite mineral. Based on mineral assemblage, It formed at $370^{\circ} \mathrm{C}-420^{\circ} \mathrm{C}$ and $<400 \mathrm{Mpa}$ [15]. It interpreted has retrograde metamorphism characterized by chlorite replacing plagioclase and actinolite.

\section{Discussion}

Mineral assemblage has a large stability range and may occur in several metamorphic facies, while other assemblages have a more restricted stability range and may be diagnostic assemblages for one facies only [15].

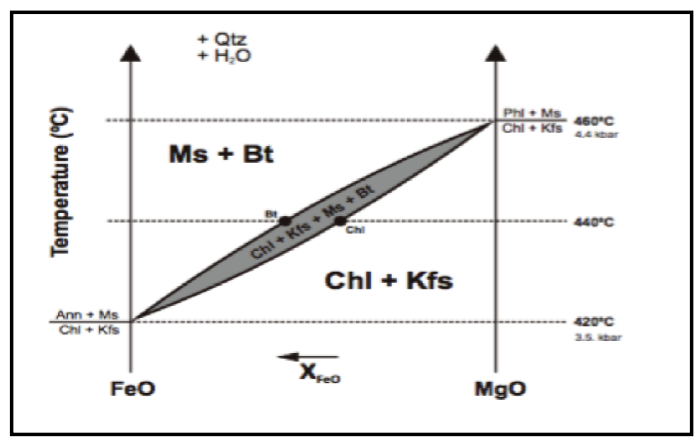

Fig. 5. Biotite - Muscovite schist formed at $440^{\circ} \mathrm{C}-460^{\circ} \mathrm{C}$ and $375 \mathrm{Mpa}$ - $440 \mathrm{Mpa}[14]$. 
TABLE 1A.

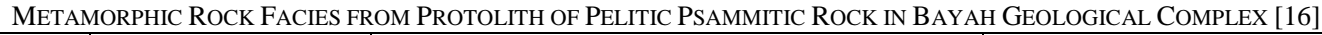

\begin{tabular}{|c|c|c|c|c|c|}
\hline \multirow[b]{2}{*}{ Metamorphic Rock } & \multirow[b]{2}{*}{ Mineral } & \multicolumn{2}{|c|}{ Medium Grade } & \multicolumn{2}{|c|}{ Low Grade } \\
\hline & & Amphibolite Facies & $\begin{array}{l}\text { Upper Greenschist } \\
\text { (Epidote- } \\
\text { amphibolite facies) }\end{array}$ & Greenschist Facies & Lower Greenschist \\
\hline \multirow[t]{4}{*}{ Chlorite Schist } & Chlorite & & & & \\
\hline & Clay Mineral & & & & \\
\hline & Plagioclase & & & & \\
\hline & Quartz & & & & \\
\hline \multirow[t]{6}{*}{ Muscovite Schist } & K-feldspar & & & & \\
\hline & Plagioclase & & & & \\
\hline & Quartz & & & & \\
\hline & Muscovite & & & & \\
\hline & Phengite & & & & \\
\hline & Chlorite & & & & \\
\hline \multirow{6}{*}{$\begin{array}{l}\text { Biotite - Muscovite } \\
\text { Schist }\end{array}$} & K-feldspar & & & & \\
\hline & Plagioclase & & & & \\
\hline & Quartz & & & & \\
\hline & Biotite & & & & \\
\hline & Muscovite & & & & \\
\hline & Chlorite & & & & \\
\hline \multirow[t]{5}{*}{ Garnet Biotite Schist } & K-feldspar & & & & \\
\hline & Quartz & & & & \\
\hline & Garnet & & & & \\
\hline & Biotite & & & & \\
\hline & Chlorite & & & & \\
\hline
\end{tabular}

TABLE 1B.

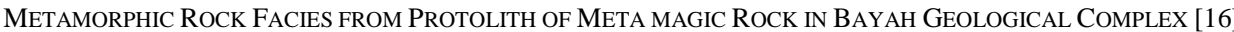

\begin{tabular}{|c|c|c|c|c|c|}
\hline \multirow[b]{2}{*}{ Metamorphic Rock } & \multirow[b]{2}{*}{ Mineral } & \multicolumn{2}{|c|}{ Medium Grade } & \multicolumn{2}{|c|}{ Low Grade } \\
\hline & & Amphibolite Facies & $\begin{array}{c}\text { Upper Greenschist } \\
\text { (Epidote- } \\
\text { amphibolite facies) }\end{array}$ & Greenschist Facies & Lower Greenschist \\
\hline \multirow[t]{4}{*}{ Actinolite Schist } & Plagioclase & & & & \\
\hline & Actinolite & & & & \\
\hline & Chlorite & & & & \\
\hline & Quartz & & & & \\
\hline \multirow{6}{*}{$\begin{array}{l}\text { Epidote Amphibolite } \\
\text { Schist }\end{array}$} & Plagioclase & & & & \\
\hline & Hornblende & & & & \\
\hline & Actinolite & & & & \\
\hline & Chlorite & & & & \\
\hline & Epidote & & & & \\
\hline & Quartz & & & & \\
\hline \multirow[t]{5}{*}{ Amphibolite Schist } & Hornblende & & & & \\
\hline & Plagioclase & & & & \\
\hline & Quartz & & & & \\
\hline & Actinolite & & & & \\
\hline & Chlorite & & & & \\
\hline
\end{tabular}

Based on mineral assemblage, metamorphic rocks in Bayah Geological Complex included lower greenschist, greenschist, upper greenschist (epidote amphibolite) and amphibolite facies. Transition lower greenschist greenschist facies is represented by chlorite schist; greenschist facies consist of muscovite schist, muscovitebiotite schist, and actinolite schist; upper greenschist (epidote-amphibolite facies) consists of garnet biotite schist and epidote amphibolite; amphibolite facies consist of hornblende schist [14].

According to a characteristic of slate - schist, they are interpreted association with low - medium pressure and temperature metamorphism, indicated by the present of chlorite schist - garnet biotite schist. As well amphibolite schist formed included with medium pressure and temperature metamorphism. According to reference [14], metamorphic rocks which formed at medium P-T metamorphism are an association with subduction and orogenic style (collision type). The metamorphic rocks exposed to the surface through several alternatives. Firstly, they exposed during uplifting in Late Cretaceous [2]. All metamorphic rocks characterize it in BGC area almost have retrograde metamorphism; in mica schist group, chlorite and muscovite replacing biotite and $\mathrm{K}$-feldspar and plagioclase 
replaced by sericite and chlorite, meanwhile in hornblende schist, hornblende altered by actinolite and chlorite, epidote and chlorite replacing plagioclase. Secondly, metamorphic rocks exposed caused by deformation followed by folded, fault and intruded by Cihara Granodiorite, so the rock has uplifted to the surface. It can be seen in some metamorphic rock fractured and filled by quartz, chlorite and epidote, also pyrite mineral.

Based on the explanation, can be concluded that basement in the Western part of Java is not only in Ciletuh Mélange Complex, but it can be found in Bayah Geological Complex. These rocks uplifted caused by accretion in Early Eocene Middle Eocene and overlain by Bayah Formation [18]. In Last Eocene - Early Oligocene, volcanism happened which result in Cikotok Formation material (Lava, tuff, and breccia). Then, still in Oligocene, there were uplifting that followed intrusion Granodiorite (Cihara).

\section{CONCLUSION}

Metamorphic rocks exposed in Bayah Geological Complex dominated by muscovite-biotite schist, some garnet biotite schist, muscovite schist, and Chlorite schist that come from pelitic rock - psammitic rock. Based on the mineral assemblage, Mica group included begins lower greenschist - epidote-amphibolite facies (Upper greenschist facies) formed at $200^{\circ} \mathrm{C}-520^{\circ} \mathrm{C}$ and $<230 \mathrm{Mpa}$ and 1100 Mpa. Other metamorphic rock present actinolite schist, epidote amphibolite, and hornblende schist, were transformed from the mafic rock. Greenschist formed at $370^{\circ} \mathrm{C}-420^{\circ} \mathrm{C}$ and $<400 \mathrm{Mpa}$ and amphibolite schist formed at $600^{\circ} \mathrm{C}-660^{\circ} \mathrm{C}$ and $400 \mathrm{Mpa}-600 \mathrm{Mpa}$. These rocks formed at medium P-T metamorphism is associated with subduction and collision type. These rocks interpreted as basement rock which exposed in Bayah area besides those of Ciletuh Melange Complex. The basement (Metamorphic rocks) uplifted caused by accretion in Early Eocene Middle Eocene and overlain by Bayah Formation. In Last Eocene - Early Oligocene, volcanism happened which result in Cikotok Formation material. Then, still in Oligocene, there were uplifting that followed by intrusion Granodiorite (Cihara) so that the rocks exposed to the surface.

\section{ACKNOWLEDGMENTS}

I would like to thank you to Directorate of Research, Community Service and Innovation (DRPMI), Padjadjaran University, Sumedang that have contributed in this research so that it works well.

\section{REFERENCES}

[1] K. Wakita, "Mesozoic mélange formation in Indonesia - with special reference to Jurassic mélanges of Japan," Geol. Soc. Malaysia Bull., vol. 45, no. August, pp. 19-30, 1999.

[2] B. Clements and R. Hall, "Cretaceous to Late Miocene stratigraphic and tectonic evolution of West Java," Proc. Indones. Pet. Assoc., no. May, pp. 1-18, 2007.

[3] R. W. van Bemmelen, The Geology of Indonesia and Adjacement Archipelagoes. 1949.

[4] R. Soekamto, "Geological Map of the Jampang and Balekambang Quadrangles, Java, Scale 1 : 100,000,” Bandung, 1975.

[5] S. Martodjojo, S. Suparka, and S. Hadiwisastra, "Status Formasi Ciletuh dalam Evolusi Jawa Barat," Geol. Indones., vol. 5, pp. 29-38, 1978.

[6] F. H. A. Hehuwat, "An Overview of some Indonesian Melange Complex a Contribution to the Geology of Melange.," Mem. Geol. Soc. China, 1986.

[7] D. M. Schiller, R. A. Garrard, and L. Prasetyo, "Eocene Submarine Fan Sedimentation in Southwest Java," in Proceedings Indonesian Petroleum Association, 1991, pp. 125-181.

[8] M. H. J. Dirk, "Studi Petrology Batuan Ofiolit dari Komplek Bancuh Ciletuh Jawa Barat," J. Geol. dan Sumberd. Miner., pp. 26-30, 1997.

[9] A. Patonah and H. Permana, "Petrology Batuan Metamorf Komplek Melange Ciletuh, Jawa Barat,” Bull. Sci. Contrib., vol. 8, no. 2, 2011.

[10] Sujatmiko and Santosa, "Peta Geologi Lembar Leuwidamar Skala 1:100.000," Bandung, 1992.

[11] A. Patonah, I. Syafrie, and H. Ayasa, "New Perspective on HighGrade Metamorphic Regional in Bayah Complex, Banten Province, Indonesia," in Proceeding 1st International Conference "Geoscience for Energy, mineral resources and environment," 2014.

[12] T. Widiaputra and A. Patonah, "Metamorphic Rocks in Bayah Complex, Banten Province: A Study in Tectonic Environment," in Proceeding Of Geosea XIV and 45th IAGI Annual Convention 2016 Ikatan Ahli Geologi Indonesia ( IAGI ), pp. 885-939, 2016,

[13] S. Martodjojo, "Evolusi Cekungan Bogor," ITB, 1984.

[14] K. Bucher and R. Grapes, Petrogenesis of Metamorphic Rocks, 8th ed. London New York: Springer, 2011.

[15] K. Bucher and M. Frey, Petrogenesis of Metamorphic Rocks, 6th ed. Berlin Heidelberg: Springer - Verlag, 1994.

[16] W. A. Deer, R. A. Howie, and J. Zussman, An Introduction to The Rock Forming Mineral, 2nd ed. Hongkong: Longman Group, 1992.

[17] L. P. Plyusnina, "Geothermometry and geobarometry of plagioclasehornblende bearing assemblages," Contrib. to Mineral. Petrol., vol. 80 , no. 2, pp. 140-146, 1982.

[18] Sribudiyani et al., "The collision of the East Java Microplate and its implication for hydrocarbon occurrences in the East Java Basin," Proc. Indones. Pet. Assoc. Twenty-ninth Annu. Conv. Exhib. Oct. 2003, no. October, pp. IPA03-G-085, 2003. 